\title{
THE MODEL OF BIOPIRACY DISPUTE SETTLEMENT IN THE FRAMEWORK OF PROTECTING TRADITIONAL KNOWLEDGE ${ }^{\Omega}$
}

\author{
Zakki Adlhiyati, Harjono, Sri Wahyuningsih Yulianti, and Moch Najib Imanullah \\ Universitas Sebelas Maret \\ E-mail: zakki.adlhiyati@yahoo.co.id
}

\begin{abstract}
Solving the problem of traditional knowledge biopiracy faced by Indonesia is the background of this article. Thereby the problem of this papers is to seek the best way to settle the dispute occurred in biopiracy case. Due to the economic value of traditional knowledge this national resources need to be protected. Due to this economic value, a lot of traditional knowledge stolen and patented by someone else, this biopiracy cases had been long faces by the developing countries i.e Indonesia with shisheido case and avian influenza (H5NI) case, India with turmeric case and basmati rice case. Judicial settlement of dispute, alternative dispute resolution, quasi judicial are a way to solve the cases which can be choose.
\end{abstract}

Keywords: biopiracy, traditional knowledge, dispute

\begin{abstract}
Abstrak
Dilatar belakangi dengan adanya biopiracy atas pengetahuan tradisional, penulis mencoba mencari solusi atas permasalahan yang juga dihadapi oleh Indonesia. solusi yang hendak dicari terkait dengan pola peyelesaian sengketa biopiracy, yang mana merupakan permasalahan atas tulisan ini. Pengetahuan tradisional adalah asset Negara yang harus dilindungi karena mempunyai nilai ekonomi. Pengetahuan tradional banyak dicuri dan kemudian didaftarkan paten karena nilai ekonominya. Beberapa kasus biopiracy yang pernah terjadi antara lain kasus shiseido (Indonesia), H5N1 (Indonesia), kasus turmeric (India), padi basmati (India). Pada beberapa kasus biopiracy tersebut ditemui beberapa pola penyelesaian sengketa antara lain judicial settlement of dispute, alternative dispute resolution, quasi judicial.
\end{abstract}

Kata kunci: biopiracy, pengetahuan tradisional, sengketa

\section{Introduction}

The Dispute of biopiracy is dispute arising due to the theft of genetic resources of indigenous peoples. One way of biopiracy is using patents. Patents registration will make product of genetic resources could be commercialized, and the owner of patent automatically have exclusive rights over the genetic resources. This means, that the other parties are forbidden to use genetic resources without the permission from the patents's owner and their have the freedom to determine prices over the genetic resources product. Some genetic resources that

$\Omega$ This paper is the result of research funded by the Ministry of research, Technology and Higher Education with a number of contract: 339/UN 27.11/PL/2015.

Imas Rosidawati Wiradirja, “Konsep Perlindungan Pengetahuan Tradisional berdasarkan Asas Keadilan Melalui Sui taken by foreign companies is the the traditional knowledge of indigenous peoples.

The concept of traditional knowledge can be applied in the sector of agriculture, (e.g. subak in Bali), Science (traditional medicine such as herbal medicine), technology (e.g. batik tulis, tempe), treatment, including folklore, geographical indication, symbol, and geographic wealth that moving. ${ }^{1}$ Traditional knowledge need to be protected because it's vulnerable as the objects of biopiracy.

Related to the protection of traditional knowledge, this research needs to be done be-

Generis Intellectual Property System", Jurnal Hukum Ius Quia lustum, Vol 2 April 2013, Yogyakarta: Fakultas Hukum Universitas Islam Indonesia 
cause of benefical to many parties including government, indigenous peoples, and also academics because this research will uncover the dispute settlement model that most appropriate with indigenous peoples which can provide the proctection of traditional knowledge. This dispute settlement model search is a novelty because previous research has not discussed about traditional knowledge of dispute settlement. Some previous research, include: Imas Rosidawati Iradirja writting about the Concept of Traditional Knowledge Protection based on the principle of fairness through Sui Generis Intellectual Property System. That research shows the concept of Intellectual Property Rights have not been able to give protection to traditional knowledge, so it's necessary to make regulations that are sui generis. ${ }^{2}$

So far, the concept of Intellectual Property Rights has not been able to provide protection of indigenous traditional as the owner of traditional knowledge. Traditional knowledge that patented by foreign companies are not allowed to be used even by indigenous peoples who have traditional knowledge, even they are required to pay for the products they use are long hereditary, it is certainly very detrimental to indigenous peoples. This is contracy to the Nagoya Protocol on Access on Genetic Resources and the Fair and Equitable Sharing of Benefit Arising from Their Utilization to the Convention on Biological Diversity.

Article 5 of the Nagoya Protocol explains that the profits resulting from the utilization of genetic resources should be shared in a fair and balanced with the providers of genetic resources. This protocol also requires that the existence of prior Inform Consent (notice) to indigenous peoples if there are other parties who want to utilize their genetic resources. Biopiracy disputes involving traditional knowledge often occur particulary with the developing countries, for example the case of shiseido and also avian influenza virus (H5N1).
Some cases are resolved through the outside of the courts, for example the case of shiseido ends with the intention from the company to cancel their patent after getting pressure from Indonesian NGOs, H5N1 case also does not reach law domain because the case is resolved with political negotiations. Both case above can also reflect the weakness legal system of Indonesian law as a developing country. The weakness of Intellectual Property Rights law system can be triggered biopiracy because the rule of law has not been enforced well it is associated with the synchronization of international and regulatory enforcement by law enforcement agencies.

\section{Problems}

The problems are: first, How is the rule of dispute settlement arrangements biopiracy?; second, are there any issues in dispute settlement in the framework of the protection of traditional knowledge?; third, what is the ideal model of dispute settlement of biopiracy over traditional knowledge?

\section{Research Methods}

The method used in this study is normative. Normative research is the research literature, the research of secondary data. ${ }^{3}$ Secondary data include the study of the literature in the form of books, journals, researchs or legislation to enrich the data and insights related to the focus of the research.

\section{Discussion \\ Arrangement of the Settlement of Biopiracy Case}

Article 27 of the United Nations on Convention on Biological Diversity (UN CBD) explained that the resolution of disputes concerning the interpretation or application of the convention can be done with the council, if no agreement is reached by the council, then the parties may seek the services of a third party interm. If with the third party interm also did not reach an

\footnotetext{
2 Ibid, Page 181
} 
agreement, then the dispute shall be resolved by arbitration or through the International Court. Based on that article, then there are at least two types of dispute resolution models. First, the Alternative dispute resolution (herein after referred to as the ADR). The concept of ADR first appeared in the United States that is backed by the presence of community discontent against the court system. The settlement of the case in the courts take a long time due to the cumulation of case, so require a great cost, and doubts the ability of judges resolve the issue complicated that require particular skills to solve them. ${ }^{4}$

$A D R$ is a dispute settlement outside the court, the dispute settlement model outside of court may be made by way of negotiation, mediation, conciliation and arbitration. Negotiation is a decision making process that is interpersonal between 2 people/more to agree on a limited resource allocation. ${ }^{5}$ Negotiation is selected by business doers as alternative main settlement of business disputes than other dispute settlement methods. ${ }^{6}$ Mediation is a dispute settlement process of the parties assisted by a neutral third party as a facilitator which the decision is based on the agreement of disputing parties. $^{7}$

Conciliation is an effort which is done by neutral third party to communicate with the dispute parties separately to reduce tension and lobbies for approval. ${ }^{8}$ Arbitration is an alternative dispute settlement where the dispute par-

$4 \quad$ Rika Lestari, “Perbandingan Hukum Penyelesaian Sengketa secara Mediasi di Pengadilan dan di Luar Pengadilan di Indonesia", Jurnal Ilmu Hukum, Volume 3 No 2, Riau: Faculty of Law, Universitas Riau, page 218-219.

5 Thomson dalam Mohammad Ilham A Hamudy, "Negosiasi dalam Reformasi Pemerintahan Daerah", Bisnis dan Birokrasi, Jurnal Ilmu Administrasi dan Organisasi, Vol.17 No. 12010 Jakarta: Faculty of Social and Political Sciences, Universitas Indonesia, page 53.

6 Agung Subakti, “Tinjauan Yuridis terhadap Konsep Negosiasi sebagai Alternatif Penyelesaian Sengketa dalam Sengketa Bisnis di Indonesia yang Berlandaskan Nilai Pancasila", Jurnal Untan, Vol 2 No 3 2013, Kalimantan Barat: Program Magister Hukum Universitas Tanjungpura, page 1

7 Asmawati, "Mediasi Salah Satu Cara dalam Penyelesaian Sengketa Pertanahan", Jurnal Ilmu Hukum, Vol. 5 No. 1 Edisi Maret 2014, Jambi: Fakulty of Law, Universitas Jambi, page 1 . ties choose one more person/who acted as "referee" who will make a decision". 9 There are two types of arbitration which is National arbitration and also international arbitration.

National Arbitration refers to Law Number 30 Year 1999 concerning arbitration and alternative dispute settlement, while international arbitration referring to the New York Convention of 1956. Article $1 \mathrm{New}$ York Convention stated that: this Convention on shall apply to the recognition and enforcement of arbitral awards made in the territory of a State other than the State where the recognition and enforcement of such awards are sought. The article above explains that the international arbitration decision is a decision made in the territory of another country of where the recognizition and execution of arbitration award upon requested. ${ }^{10}$ The international arbitration decision is recognized and can be implemented in Indonesia, but ther resolution should be through ICSID (International Centre for the Settlement of Investment Disputes) and on condition that, international arbitration decision imposed by the arbitrator or the Arbitration Tribunal in a country with Indonesia bound an agreement, both billateral or multilateral. ${ }^{11}$

Second, judical dispute settlement is a model dispute settlement through the court. Now the International Tribunal has been emerging, because of a tendency to settle the case through an International Tribunal. ${ }^{12}$ This is due to the hopes of the justice seekers, although

8 Sapuan Dani, "Sengketa Hak Guna Usaha dan Masyarakat", Justice Magazine, Vol. 15 No 1 Juni 2015, Bengkulu: Universitas Prof Dr Hazairin, page 8.

9 Syahda Guruh LS, "Arbitrase sebagai Alternative Penyelesaian Sengketa Investasi", Opinio Juris, Vol. 1 Oktober 2009, Jakarta: Kementerian Luar Negeri, page 24.

10 Grace Henni Tampongangoy, “Arbitrase Merupakan Upaya Hukum dalam Penyelesaian Sengketa Dagang Internasioanal”, Lex Et Societatis, Vol. 3, No. 1, Jan-Mar 2015, Sulawesi Utara: Bagian Hukum dan Masyarakat Fakultas Hukum Universitas Sam Ratulangi, page 7.

11 Soemali \& Lidia Noor Yulyanti, "Penyelesaian Sengketa Melalui Arbitrase dalam Investasi Perdagangan", Jurnal Hukum, Vol. XVIII, No. 18, April 2010, Surabaya: Fakultas Hukum Universitas Narotama, page 63.

12 Keohane Robert O, et al, "Legalized Dispute Resolution: Interstate and Transnational", International Organization, Vol. 54, Issue 03 June 2000, United Kingdom: University of Cambrigde, page 457. 
international agencies faced with their weakness of the power/authority. ${ }^{13}$ Several international courts, such as the Permanent Court of International Justice $(\mathrm{PCIJ})$, the International Court of Justice (ICJ), the Interntional Criminal Court (ICC), and The International Tribunal for the Law of The Sea (UNCLOS 1982). ${ }^{14}$

Related to Intellectual Property Rights disputes in the international sphere, the WTO has a special body authorized to resolve the Dispute, i.e. the Dispute Settlement Body, the role of a pannels, and Appellate body to determine claims brought under the dispute settlement provisions of the various WTO Agreements. ${ }^{15}$ Dispute Settlement Body is a quasi judicial institutions that resolve disputes of the trade.

Indonesia, at least there are two laws relating to dispute settlement cases of biopiracy traditional knowledge, namely Patent Law, and Protection of Plant Varieties Law. Law number 29 Year 2000 concerning the protection of Plant Varieties (PPV) provides the protection of traditional knowledge that are included on the local varieties, i.e. the existing varieties and cultivated hereditary by farmers as well as to belong to the community, so the dispute settlement as regulated in this law may be used as a reference for settling disputes on traditional knowledge biopiracy. Based on article 7 of the PPV law, then the local varieties controlled by the country, as a consequence the country should protect the local varieties. PPV law uses the judicial dispute settlement as the way to settle the case as mentioned in article 66 which provides the basic for the State Court to resolve the case of claims for infringement of plant variety protection. Based on this, so if there is a dispute over biopiracy traditional knowledge in the domestic realm can be field and resolved in the State Court.

13 Aloysius P. Llamzon, "Jurisdiction and Compliance in Recent Decisions of the International Court of Justice", The European Journal of International Law, Vol. 18 No. 5, 2008, Europe: Europian University Institute, page 815

14 Popi Tuhulele, "Pengaruh Keputusan Mahkamah Internasional Dalam Sengketa Pulau Sipadan dan Ligitan Terhadap Penetapan Garis Pangkal Kepulauan Indonesia”,
Regarding the patent law clearly divide the settlement of the case into two cases which are criminal case and civil case. The settlement of a criminal case can be taken related to violations of the exclusive rights of the patent holder and also violation of the obligation of the authority to maintain the confidentiality of the invention, where a criminal case is resolved in State Court. The settlement of a civil case can be done through the commercial court. The commercial court related to a patent dispute, has some of the competencies. First, complete the case of dispute how the calculation and determination of the inventor's remuneration with the giver of work; second, lawsuit rejection substantive examination of patent appeals commission; third, the revocation of the patent. Fourth, the patent granted to parties other than entitled; fourth, lawsuit against exclusive rights abuses; fifth, the issuance of a temporary assignment letter; and sixth, changing, cancelling, and strengthened temporary assigment.

Additionally, the Patent Law also mentions the existence of a settlement civil case through civil appeals commision patenting, related to the substantive application was disapproved. The resolution of the case through the appeals commision patenting is a form of dispute resolution through the quasi judicial.

The Patent Law also gives the option to settle the case through arbitration or alternative dispute settlement. The weakness of the Patent Act is not covering the protection of traditional knowledge, because the patent only protects the new invention, has inventive step and can be applied in the industry. Based on the preconditions, then patent dispute through judicial settlement can be reached if there is a dispute of biopiracy related traditional knowledge because the law clearly limits the scope of patent protection above the new invention while traditional knowledge is knowledge that is passed down

Jurnal Sasi Vol. 17 No. 2 Edisi April - Juni 2011, Maluku: Faculty of Law Universitas Pattimura, page 2.

15 Lorand Bartels, "The Separation of Powers in The WTO: How to Avoid Judicial Activism", Cambridge Journals, Vol 53 October 2004, United Kingdom: University of Cambridge, page 863-864. 
orally from generation to generation in a community so that if traditional knowledge registered patents, then it does not qualify novelty and inventive step that can be filed the lawsuit patent to the Commercial Court, biopiracy disputes can also be resolved by arbitration or by other forms of $A D R$, but quasi-judicial dispute resolution through patent appeals commission can not be reached due to the cancellation of the patent is not a patent appeal the Commission's jurisdiction.

\section{Problems in Bioporacy Dispute Settlement in the Framework of Protecting Traditional Knowledge}

The theft of traditional knowledge is often involving developing countries, there are few example in Indonesia. First the Shiseido case, Shiseido is a Japanese company that manufactures beauty tools such as anti-aging and shampoo. In 1990 Shieseido has patented 11 Indonesian traditional herbs. One of them is sambiloto that used for anti aging drug. ${ }^{16}$ Biotani (NGO) propose resistance to Shiseido, and in 2002, Shiseido draw their patent.

Second, the Avian Influenza Case, during 2004-2005 Indonesia sends samples of Avian Influenza Virus (H5N1) to the WHO (the World Health Organization). DNA virus $\mathrm{H} 5 \mathrm{NI}$ description stored in the laboratory that is controlled by the Ministry of energy of the United States, but then emerged the top vaccine patent $\mathrm{H} 5 \mathrm{NI}$ by drug companies, and they selling this product in Indonesia with high prices. In 2005 Indonesia stopped sending samples of the virus and asked for information disclosure over a given sample, which is then given by the WHO in 2007. ${ }^{17}$

Some cases of biopiracy above occurred within the jurisdiction of another country, shisheido for example is a cosmetics company based in Japan and registered the patent of native plants of Indonesia in Tokyo Patent Office, then if the parties use the judicial settlement to complete the case, the Court is competent to settle shoseido biopiracy case is performed by the

16 Afifah Kusumadara, 2000, Analysis of The Failure of The Implementation of Intellectual Property Laws in Indone- courts located in Japan, because of the principle Actor Secuitur Forum Rei, The Court is authorized to settle the lawsuit are court domicile area the Defendants. The principle is also recognized and used in Japan. Article 3 the Japan Civil Code Procedure (Book of the Criminal Procedure Law of Japan) stated as follows:

Art.3-2(1) JCCP: The courts shall have jurisdiction over an action against a person: - if he/she has his/her domicile in Japan. Art.3-2(3)JCCP: The courts shall have jurisdiction over an action against a juridical person or any other association or foundation, if its principal office or business office is located in Japan.

The second problem is the lack of regulations governing the protection of traditional knowledge in the sphere of intellectual property rights in Indonesia. Absence of this Law become problems in the process of dispute settlement, it's because the patent and plant variety protection models have different judicial dispute settlement. Dispute settlement the judical patents is in the commercial court, meanwhile the judicial of dispute settlement for plant variaties protection is in the State Court. Such seperation can confused people, so it needs to established a new Law regulating the protection of traditional knowledge associated with the utilization of intellectual property rights, where in the legislation needs to be about dispute settlement of traditional knowledge.

\section{The Ideal Model of Bioporacy Dispute Sett- lement}

Indonesia is a country based on Pancasila, in Pancasila there are values that emphasize the existence of dispute settlement through consensus discussion, so that the dispute settlement biopiracy of traditional knowledge is the most appropriate with consensus discussion. Dispute settlement consensus discussion can be institution through dispute settlement of negotiations, and mediation that are included on the types of ADR. Through negotiations the parties have a di-

sia, Thesis, Australia: Faculty of Law University of Sydney.

17 Ibid 
rect meeting to disscuss and make agreements. The results of the negotiations poured in a written agreement. Mediation can be reached if the negotiations did not success, that dispute settlement through helping from an expert, expert advisor or a mediator.

The next ideal model is a quasi judicial, this model is the second alternative if the discussion did not sucees. Quasi Judicial has been applied in patent dispute settlement through the Patent Appeal Commision, the patent appeal Commision but has no competence to cancel a patent that already registered. In Indonesia the cancellation of patents is a competence of the Commercial Court, then Commercial Court will instruct the Ministry Directorate General of Intellectual Property Rights to cancel that patent, the weakness of this system is a long process of administration is required to cancel the patent. This weakness is the reason it needs to expanse the competence of the Patent Appeal Commision to cancel a patent.

Cancellation of the patent through quasi judicial basically been used also in the patent cancellation process in the United States. In the United States, an objection to patents that have issued may be filed through the mechanism of "patent reexamination" at USPTO.

The US currently has two avenues for challenging the validity of a patent: the PTO's reexamination procedures \& invalidation through the courts. At present, the PTO will reexamine patents via two mechanisms: reexamination and inter partes reexamination. ${ }^{18}$ Quasi-judicial dispute settlement is cheaper and faster than the process of dispute settlement in court.

\section{Conclusion}

Dispute settlement biopiracy of traditionnal knowledge stipulated in Article 27 of the United Nations on Convention on Biological Diversity (UN CBD), which explains the convention dispute settlement can be done by consensus, mediation, arbitration or through international courts. In Indonesia, the biopiracy dispute sett-

18 Jay P. Kesan dan Gwendolyn G. Ball, "How Are Patent Cases Resolved? An Empirical Examination of the Adjudication and Settlement of Patent Disputes", Washington lement regulation of traditional knowledge is still included in the Patent Law and PVP law, because Indonesia does not have legislation regulating the protection of traditional knowledge related to its intellectual property rights.

The absence of legislation regulating the protection of traditional knowledge becomes the problems in the process of dispute settlement, because patents and PVP models have different judicial dispute settlement. Patent judicial dispute settlement is in the Commercial Court while PVP judicial dispute resolution is at the State Court. The existence of such separation can confuse the public.

Some models of biopiracy dispute settlement of traditional knowledge can be applied to adjust the characteristics of the Indonesian that emphasizes deliberation, including mediation and negotiation. The second model is the quasi judicial by increasing the competence of patent appeal commission and appeal commission of plant variety protection as a patent dispute settlement and protection of plant varieties associated with certificate revocation.

\section{Suggestion}

It is necessary to establish laws regulating the protection of traditional knowledge and utilization of intellectual property rights, Law of protection of traditional knowledge and utilization of intellectual property rights are necessary to regulate settlement of dispute, either through consensus discussion (mediation and negotiation), arbitration, quasi-judicial, or through judicial settlement.

\section{References}

Asmawati. "Mediasi Salah Satu Cara dalam Penyelesaian Sengketa Pertanahan". Jurnal Ilmu Hukum, Maret 2014. Jambi: Fakulty of Law, Universitas Jambi;

Bartels, Lorand. "The Separation of Powers in the WTO: How to Avoid Judicial Activism". Cambridge Journals, Vol 53 October 2004. United Kingdom: University of Cambridge; 
Dani, Sapuan. "Sengketa Hak Guna Usaha dan Masyarakat", Justice Magazine, Volume 15 No 1, Juni 2015, Bengkulu: Universitas Prof Dr Hazairin;

Hamudy, Mohammad Ilham A. "Negosiasi dalam Reformasi Pemerintahan Daerah". Bisnis dan Birokrasi, Jurnal Ilmu Administrasi dan Organisasi, Vol. 17 No. 1 2010. Jakarta: Faculty of Social and Political Sciences, University Indonesia;

Kesan Jay P. dan Gwendolyn G. Ball. "How Are Patent Cases Resolved? An Empirical Examination of the Adjudication and Settlement of Patent Disputes". Washington University Law Review, Volume 84 Issue 2, 2006. St. Louis: Washington University;

Kusumadara, Afifah. 2000. Analysis of the Failure of the Implementation of Intellectual Property Laws in Indonesia. Thesis, Faculty of Law, University of Sydney, Australia;

Lestari, Rika. "Perbandingan Hukum Penyelesaian Sengketa secara Mediasi di Pengadilan dan di Luar Pengadilan di Indonesia”. Jurnal Ilmu Hukum, Vol. 3 No 2. Riau: Faculty of Law, Universitas Riau;

Llamzon, Aloysius P. “Jurisdiction and Compliance in Recent Decisions of the International Court of Justice". The European Journal of International Law, Vol. 18 no.5, 2008. Europe: Europian University Institute;

LS, Syahda Guruh. “Arbitrase sebagai Alternative Penyelesaian Sengketa Investasi". Opinio Juris, Vol. 1 Oktober 2009. Jakarta: Kementerian Luar Negeri;

Robert O, Keohane. et al. "Legalized Dispute Resolution: Interstate and Transnational". International Organization, Vol. 54 Issue
03 June 2000. United Kingdom: University of Cambrigde;

Soemali \& Lidia Noor Yulyanti. "Penyelesaian Sengketa Melalui Arbitrase dalam Investasi Perdagangan”, Jurnal Hukum, Vol. XVIII, No. 18, April 2010, Surabaya: Faculty of Law, Universitas Narotama;

Soemitro, Ronny Hanitijo. 1988. Metodologi Penelitian Hukum dan Jurimetri. Jakarta: Ghalia;

Subakti, Agung. "Tinjauan Yuridis terhadap Konsep Negosiasi sebagai Alternatif Penyelesaian Sengketa dalam Sengketa Bisnis di Indonesia yang Berlandaskan Nilai Pancasila”. Jurnal Untan, Vol 2 No 3 2013. Kalimantan Barat: Program Magister Hukum Universitas Tanjungpura;

Tampongangoy, Grace Henni. “Arbitrase Merupakan Upaya Hukum dalam Penyelesaian Sengketa Dagang Internasioanal”. Lex Et Societatis, Vol. III, No. 1, Jan-Mar 2015. Sulawesi Utara: Bagian Hukum dan Masyarakat, Fakultas Hukum, Universitas Sam Ratulangi;

Tuhulele, Popi. “Pengaruh Keputusan Mahkamah Internasional dalam Sengketa Pulau Sipadan dan Ligitan terhadap Penetapan Garis Pangkal Kepulauan Indonesia”. Jurnal Sasi, Vol. 17 No. 2 Bulan April - Juni 2011. Maluku: Faculty of Law, Universitas Pattimura;

Wiradirja, Imas Rosidawati. “Konsep Perlindungan Pengetahuan Tradisional berdasarkan Asas Keadilan Melalui Sui Generis Intellectual Property System". Jurnal Hukum Ius Quia lustum, Vol 2 April 2013. Yogyakarta: Law Faculty, Universitas Islam Indonesia. 